\title{
Fish as Hosts of Vibrio cholerae
}

\author{
Malka Halpern ${ }^{1,2 *}$ and Ido Izhaki ${ }^{2}$ \\ ${ }^{1}$ Department of Biology and Environment, Faculty of Natural Sciences, University of Haifa, Tivon, Israel, ${ }^{2}$ Department of \\ Evolutionary and Environmental Biology, Faculty of Natural Sciences, University of Haifa, Haifa, Israel
}

Vibrio cholerae, the causative agent of pandemic cholera, is abundant in marine and freshwater environments. Copepods and chironomids are natural reservoirs of this species. However, the ways $V$. cholerae is globally disseminated are as yet unknown. Here we review the scientific literature that provides evidence for the possibility that some fish species may be reservoirs and vectors of $V$. cholerae. So far, $V$. cholerae has been isolated from 30 fish species (22 freshwater; 9 marine). $V$. cholerae 01 was reported in a few cases. In most cases $V$. cholerae was isolated from fish intestines, but it has also been detected in gills, skin, kidney, liver and brain tissue. In most cases the fish were healthy but in some, they were diseased. Nevertheless, Koch postulates were not applied to prove that $V$. cholerae and not another agent was the cause of the disease in the fish. Evidence from the literature correlates raw fish consumption or fish handling to a few cholera cases or cholera epidemics. Thus, we can conclude that $V$. cholerae

OPEN ACCESS

Edited by:

Mike Taylor,

University of Auckland, New Zealand

Reviewed by:

Diane McDougald,

University of New South Wales,

Australia

Yan Boucher

University of Alberta, Canada

*Correspondence:

Malka Halpern

mhalpern@research.haifa.ac.il

Specialty section:

This article was submitted to

Microbial Symbioses,

a section of the journal

Frontiers in Microbiology

Received: 04 December 2016

Accepted: 09 February 2017

Published: 28 February 2017

Citation:

Halpern M and Izhaki I (2017) Fish as Hosts of Vibrio cholerae.

Front. Microbiol. 8:282.

doi: 10.3389/fmicb.2017.00282 inhabits some marine and freshwater fish species. It is possible that fish may protect the bacteria in unfavorable habitats while the bacteria may assist the fish to digest its food. Also, fish may disseminate the bacteria in the aquatic environment and may transfer it to waterbirds that consume them. Thus, fish are reservoirs of $V$. cholerae and may play a role in its global dissemination.

Keywords: fish, Vibrio cholerae, waterbird, bacteria-fish interactions, reservoir, vector

\section{INTRODUCTION}

The devastating disease, cholera, is known to occur globally causing epidemics and pandemics. However, the way this disease is worldwide disseminated is still unknown. Vibrio cholerae, the causing agent of cholera is ubiquitous in marine and freshwater aquatic environments. Copepods (Crustacean) (Colwell and Huq, 2001) and chironomids (Diptera; Chironomidae) (Broza and Halpern, 2001; Halpern et al., 2004, 2006, 2007; Senderovich et al., 2008; Halpern and Senderovich, 2015) were described as natural reservoirs of $V$. cholerae. Copepods and chironomids are abundant in fresh and marine water ecosystems and are consumed by different fish species. Halpern et al. (2008) raised the hypothesis that fish that feed on copepods and chironomids, and waterbirds that also may feed on these invertebrates and consume fish as well, may be reservoirs and vectors of $V$. cholerae. Here we review the scientific literature that indicates that fish are indeed significant reservoirs of $V$. cholerae in water ecosystems.

\section{Vibrio cholerae}

$V$. cholerae, a Gram-negative motile rod causes massive cholera outbreaks such as the one following the 2010 earthquake in Haiti (Sack et al., 2004; Chin et al., 2011; Katz et al., 2013). Cholera is a 
global threat to public health and it was estimated that between 2008 and 2012 cholera caused an annual average of 2.9 million cases, and 95,000 deaths, worldwide (Ali et al., 2015). Particular serogroups (O1 and O139) of this bacterium are responsible for cholera epidemics and pandemics. Human infection with $V$. cholerae begins with ingestion of contaminated food or water containing the bacterium. $V$. cholerae colonizes the small intestine and secretes cholera enterotoxin (CT) into the host cells resulting in rapid efflux of chloride ions and water into the lumen of the intestine, leading to profuse diarrhea and severe dehydration (Kaper et al., 1995).

Non-O1/non-O139 V. cholerae serogroups are also linked to $V$. cholerae gastroenteritis as well as to wound infections and bacteremia (Deshayes et al., 2015). V. cholerae O1, O139 and nonO1/O139 comprise a single taxonomic species and their habitats attributes are similar (Lewin, 1996), however, recently it has been suggested that not all strains of $V$. cholerae species share the same niche (Kirchberger et al., 2016). The role of CT in the environment is not understood.

$V$. cholerae is commonly associated with chitin-containing zooplankton, particularly copepods (Huq et al., 1983) and chironomids (Broza and Halpern, 2001; Halpern et al., 2004). Recent evidence supports the hypothesis that fish and waterbirds may also be intermediate reservoirs and vectors of $V$. cholerae (Halpern et al., 2008; Halpern and Izhaki, 2010).

\section{Fish as Possible Reservoirs of V. cholerae V. cholerae 01 and 0139 Serogroups in Fish}

In a laboratory experiment that was conducted more than 50 years ago, Felsenfeld (1963), infected sardines (Stolephorus) and mullets (Liza) with pathogenic $V$. cholerae O1 strains (Ogawa and Inaba). Vibrio concentration in the water was $10^{2}$ cells $/ \mathrm{ml}$. The strains were detected in the fish intestine after the fish were exposed to the bacteria (Table 1). In another laboratory experiment, Runft et al. (2014) used V. cholerae O1 strains to colonize zebrafish gut. They found that the bacteria attached to the fish intestinal epithelium and formed micro-colonies. They suggested that zebrafish can act as a host model for pathogenic V. cholerae strains (Rowe et al., 2014; Runft et al., 2014) (Table 1). Evidence for the presence of pathogenic serogroups of $V$. cholerae in fish was published by du Preez et al. (2010) who detected large numbers of $V$. cholerae $\mathrm{O} 1$ and $\mathrm{O} 139$ in fish scale samples collected in Mozambique. These researchers obtained their evidence by a direct fluorescent antibody technique. $V$. cholerae O1, positive for cholera toxin gene, was isolated from Tilapia gills in Tanzania (Hounmanou, 2015). V. cholerae O1 isolates, positive to $\operatorname{ct} x A$ and $t c p A$ genes were detected from two marine fish in Cochin, India (no details were given as to the fish species) (Kumar and Lalitha, 2013). In the same study, Kumar and Lalitha (2013) also identified 141 non-O1/O139 isolates from unidentified marine fish species (Table 1).

\section{V. cholerae Non-01/0139 in Fish}

Carvajal et al. (1988) identified $V$. cholerae non-O1/O139 serogroups in healthy Lorna fish (Sciaena deliciosa) sampled from inshore marine sites during a Peruvian cholera epidemic (Table 1). Senderovich et al. (2010) examined freshwater and marine fish species. Ten freshwater (71\%) and one marine (2.3\%) fish species tested positive for the presence of $V$. cholerae non-O1/O139 in their intestine (Table 1). V. cholerae nonO1/O139 was also detected in four fish species collected from the Fowl River in the Gulf of Mexico (Jones et al., 2013) (Table 1). The prevalence of $V$. cholerae isolates in Tilapia (Oreochromis niloticus) intestines, sampled from a water reservoir in Ouagadougou, Burkina Faso in Africa, was 6.3\% (Traoré et al., 2014) (Table 1). In Qingdao in China, $V$. cholerae was detected by means of metagenomic tools in the gastrointestinal tract of a farmed adult turbot fish (Scophthalmus maximus) (Xing et al., 2013). In India, V. cholerae was isolated from two fish species (Bulls eye, Priacanthus hamrur and Hard tail scad, Megalaspis cordyla) caught off Royapuram coast (Sujatha et al., 2011) (Table 1). When the microbial quality and safety of Pangasius fish processed for export in Vietnam was evaluated, V. cholerae was isolated from tra fish (Pangasius hypophthalmus) fillets and from the water used to rinse them (Thi et al., 2014) (Table 1).

\section{V. cholerae Isolated from Diseased Fish}

A few studies have reported the isolation of $V$. cholerae nonO1/O139 from diseased fish. $V$. cholerae was isolated from internal organs of diseased ayu (Plecoglossus altivelis) and guppy fish (Poecilia reticulate) in Japan and Iran, respectively (Yamanoi et al., 1980; Kiiyukia et al., 1992; Kiani et al., 2016) and from Nile tilapia (Oreochromis niloticus) that were cultured in floating cages in Thailand (Dong et al., 2015) (Table 1). Rehulka et al. (2015) demonstrated that an intraperitoneal injection of $V$. cholerae into common carp, rainbow trout and common nase caused the death of the injected fish (Table 1).

\section{Indirect Evidence on the Possible Presence of $V$. cholerae in Fish}

According to the Hong Kong Food and Environmental Hygiene Department, $V$. cholerae serotype Ogawa biotype El Tor was found in a supermarket fish tank water in Pok Fu Lam in September 2003 (Press Release, 2003). They were not able to explain the source of the bacteria. $V$. cholerae $\mathrm{O} 1$ was detected from aquarium water and fish imported from Thailand and Sri Lanka to Czech Republic (Plesník and Procházková, 2006). Using molecular methods, Smith et al. (2012), identified V. cholerae from aquarium water containing common goldfish (Carassius auratus) purchased from aquarium shops in Rhode Island (Table 1). When the bacterial community of zebrafish intestinal tracts was studied using cloning of the 16S rRNA gene, $V$. cholerae was found as the dominant OUT in the Gammaproteobateria class (Lan and Love, 2012).

\section{Epidemiological Evidence of Fish Consumption as the Cause of Cholera}

Evidence from the literature correlated fish with a few cholera cases or epidemics. The first records date back over more than 50 years. It was postulated that cholera endemicity in India was due to hilsa fish (Pandit and Hora, 1951) (Table 2). Morgan et al. (1960), suggested that the origin of El Tor vibrios outbreaks in Thailand might have been fish that are often eaten raw in 
TABLE 1 | Isolation of $V$. cholerae strains from healthy fish species that were sampled from different habitats and regions around the world.

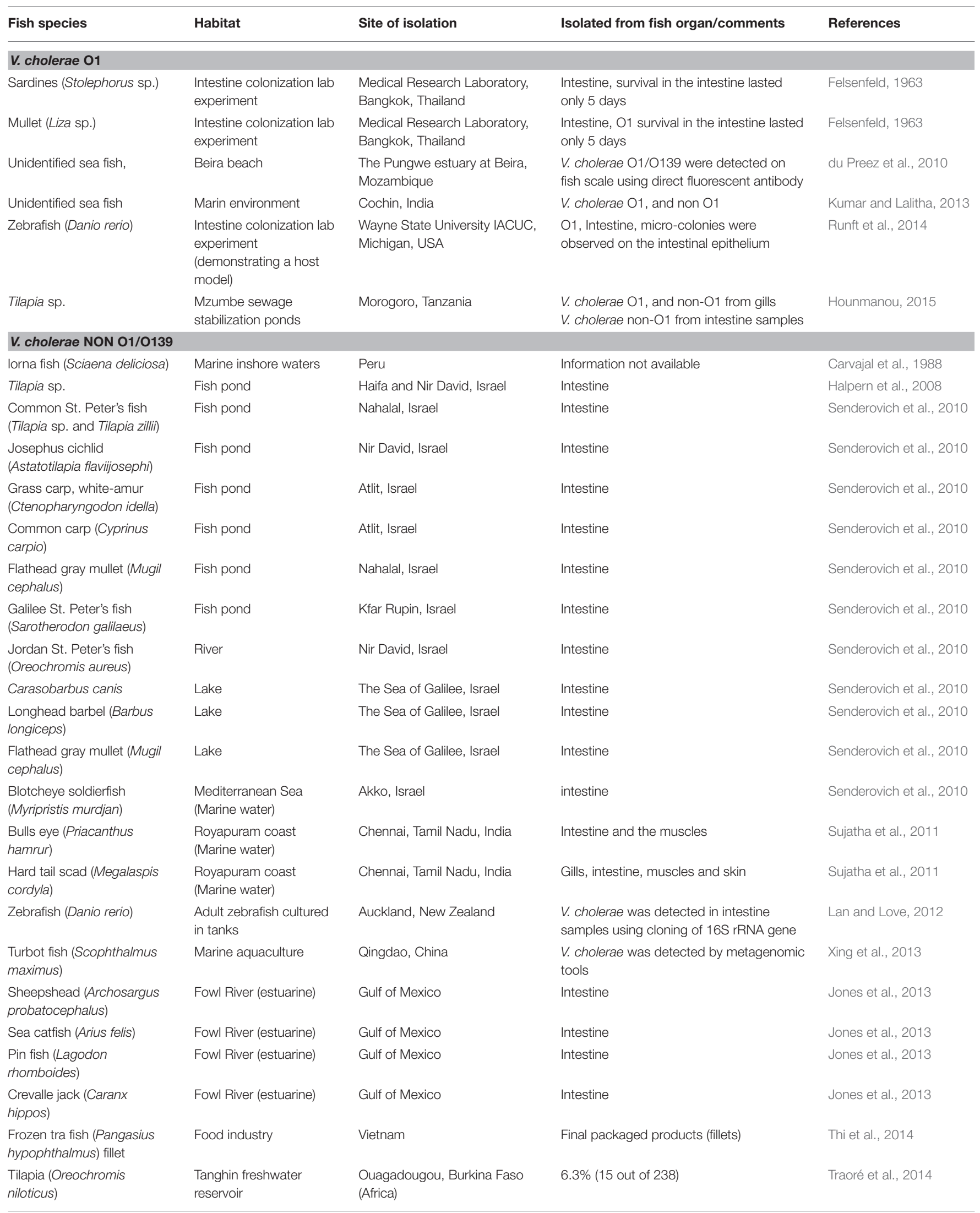


TABLE 1 | Continued

\begin{tabular}{|c|c|c|c|c|}
\hline Fish species & Habitat & Site of isolation & Isolated from fish organ/comments & References \\
\hline \multicolumn{5}{|c|}{ INDIRECT INDICATION FOR V. cholerae PRESENCE IN FISH } \\
\hline Unknown tropical fish & Water from Fish tank & UK & Reported to be the cause of a wound & Booth et al., 1990 \\
\hline $\begin{array}{l}\text { Common goldfish } \\
\text { (Carassius auratus) }\end{array}$ & Aquarium water & Rhode Island & Indication using molecular methods & Smith et al., 2012 \\
\hline \multicolumn{5}{|c|}{ V. cholerae ISOLATED FROM DISEASED FISH } \\
\hline $\begin{array}{l}\text { Ayu fish (Plecoglossus } \\
\text { altivelis) and Guppy Fish } \\
\text { (Poecilia reticulate) }\end{array}$ & River & Japan & Livers, spleens, or kidneys of diseased fish & $\begin{array}{l}\text { Yamanoi et al., 1980; } \\
\text { Kiiyukia et al., } 1992\end{array}$ \\
\hline Goldfish (Carassius auratus) & No data available & No data available & No data available & Reddacliff et al., 1993 \\
\hline $\begin{array}{l}\text { Nile tilapia (Oreochromis } \\
\text { niloticus) }\end{array}$ & $\begin{array}{l}\text { Floating cage cultured } \\
\text { Nile tilapia farms }\end{array}$ & Mekong River, Thailand & $\begin{array}{l}V . \text { cholerae from internal organs of } \\
\text { diseased fish }\end{array}$ & Dong et al., 2015 \\
\hline $\begin{array}{l}\text { Guppy Fish (Poecilia } \\
\text { reticulate) }\end{array}$ & Aquaculture ponds & Kasha, Iran & $\begin{array}{l}\text { Skin, gill, kidney and brain tissue from } \\
\text { diseased fish }\end{array}$ & Kiani et al., 2016 \\
\hline $\begin{array}{l}\text { Cardinal tetra } \\
\text { (Paracheirodon axelrodi) }\end{array}$ & Fish aquarium & Czech Republic & Diseased fish & Rehulka et al., 2015 \\
\hline $\begin{array}{l}\text { Raphael catfish (Platydoras } \\
\text { costatus) }\end{array}$ & Fish aquarium & Czech Republic & Diseased fish & Rehulka et al., 2015 \\
\hline $\begin{array}{l}\text { Common nase } \\
\text { (Chondrostoma nasus) }\end{array}$ & Fish aquarium & Czech Republic & Diseased fish & Rehulka et al., 2015 \\
\hline
\end{tabular}

the Pacific area. Cholera was associated with eating salted fish, sardines and other fish from an atoll lagoon in the Pacific Ocean (Merson et al., 1977; Kuberski et al., 1979; McIntyre et al., 1979). A cholera outbreak in Tanzania (67 patients, including 11 deaths) was correlated with handling and eating fish at social gatherings (Killewo et al., 1989). Out of 12 cholera cases caused by $V$. cholerae O1, serotype Ogawa, biotype El Tor, in the southern Italian region of Puglia, in 1994, three patients reported consumption of raw fish (Maggi et al., 1997) (Table 2). Consumption of dried fish correlated significantly with cholera risk in Tanzania (Acosta et al., 2001). In July 2001, a case of cholera, caused by $V$. cholerae O1, serovar Inaba, biovar El Tor, was reported in Berlin. Interestingly, the patient had most likely been infected while handling and preparing fish imported from Nigeria (Schürmann et al., 2002). A food traceback investigation following three cases of cholera in Sydney, Australia, found that the only exposure common to all cases was consumption of raw whitebait imported from Indonesia (Forssman et al., 2007). V. cholerae O1 serovar Ogawa was identified as the causative agent in all three cases. $V$. cholerae non-O1 was isolated from stools of a fisherman who had fished, cooked and eaten a lake fish in Italy (Piantieri et al., 1982). The source of Vibrio cholerae non-O1 that was found in a wound, was linked with a tropical fish tank (Booth et al., 1990) (Table 2).

\section{V. cholerae and Fish-Mutualistic Interactions?}

A few publications (mentioned above and in Table 1), correlated the presence of $V$. cholerae with a disease in fish (Yamanoi et al., 1980; Kiiyukia et al., 1992; Dong et al., 2015; Rehulka et al., 2015; Kiani et al., 2016). Kiiyukia et al. (1992), who isolated $V$. cholerae non-O1/O139 from diseased ayu fish in Japan, emphasized that healthy ayu fish caught in Lake Biwa, Japan in the rivers running into this lake, also harbored $V$. cholerae but without showing any signs of a disease. Kiani et al. (2016) isolated $V$. cholerae along with other pathogens from diseased Nile tilapia that were cultured in floating cages in Thailand. However, it was not proven that $V$. cholerae was indeed the causative agent of the disease (Table 1). All the above studies simply assumed that because they isolated $V$. cholerae from the diseased fish, this species was responsible for the disease. Rehulka et al. (2015) injected a fish with relatively large dose of bacteria (e.g., $2 \times 10^{8}$ cells) to obtain fish mortality but without following all Koch postulates rules. Hence we argue that at least for some cases other bacterial species or viruses and not $V$. cholerae were probably responsible for the fish disease (Table 1).

Senderovich et al. (2010) isolated $V$. cholerae from 15 different heathy fish species. They found $5 \times 10^{3}$ and $1.4 \times 10^{2}$ colony forming units (cfu) of $V$. cholerae per gr intestine content in Sarotherodon galilaeus (Galilee St. Peter's fish) and in Mugil cephalus (Flathead gray mullet), respectively. None of these fish showed any signs of disease. Nevertheless, there is a scarcity of quantitative studies of $V$. cholerae in fish. Many other studies reported the presence of $V$. cholerae in different healthy fish species that were sampled from both marine and freshwater habitats (listed in Table 1) but these studies did not quantify the numbers of $V$. cholerae in the fish.

Not all the fish species are inhabited by $V$. cholerae. For example, Jones et al. (2013) detected $V$. cholerae only in 4 out of 10 fish species sampled in the Gulf of Mexico (estuarine habitat). Similarly, Senderovich et al. (2010) did not detect V. cholerae in 4 out of 14 freshwater and in 43 out of 44 marine fish species. Scrutiny of the list of the fish species found to host $V$. cholerae revealed that all belonged to Actinopterygii class (Table S1). $V$. cholerae was identified from 30 species belonging to 9 different orders within this class. 
TABLE 2 | Fish consumption as the source of cholera disease.

\begin{tabular}{|c|c|c|c|c|}
\hline Etiology & Fish source & Site & Serogroup & References \\
\hline $\begin{array}{l}\text { Hilsa fish (Hilsa ilisa) was connected to the } \\
\text { transmission of endemic cholera. Hilsa fish, } \\
\text { infected with V. cholerae breeds abundantly } \\
\text { in the Hoogly river that runs through Calcutta }\end{array}$ & India & $\begin{array}{l}\text { Cholera endemicity in India } \\
\text { due to the Hilsa fish }\end{array}$ & V. cholerae $\mathrm{O} 1$ & Pandit and Hora, 1951 \\
\hline Eating of raw fish & Thailand & Outbreaks in Thailand, 1959 & V. cholerae O1El Tor & Morgan et al., 1960 \\
\hline $\begin{array}{l}\text { Correlated with handling and eating fish at } \\
\text { social gatherings }\end{array}$ & Tanzania & Cholera outbreak in Tanzania & V. cholerae $\mathrm{O} 1$ & Killewo et al., 1989 \\
\hline Fishing, cooking and eating a lake fish & A lake in Italy & Italy & V. cholera non $\mathrm{O} 1$ & Piantieri et al., 1982 \\
\hline Eating of raw fresh and smoked fish & Guinea & Conakry, Guinea & V. cholerae $\mathrm{O} 1$ & St. Louis et al., 1990 \\
\hline Eating of small salted fish & The Pacific Ocean & Island of Guam, 1974 & & Merson et al., 1977 \\
\hline Salted fish & The Pacific Ocean & Gilbert Island 1977 & & $\begin{array}{l}\text { Mclntyre et al., 1979; } \\
\text { Kuberski et al., } 1979\end{array}$ \\
\hline $\begin{array}{l}\text { A cholera outbreak in ( } 67 \text { patients, including } \\
11 \text { deaths) was correlated with handling and } \\
\text { eating fish at social gatherings }\end{array}$ & Tanzania & $\begin{array}{l}\text { Butiama village of the Mara } \\
\text { Region, Tanzania }\end{array}$ & V. cholerae $\mathrm{O} 1$ & Killewo et al., 1989 \\
\hline $\begin{array}{l}\text { Consumption of raw fish illegally imported } \\
\text { from Albania }\end{array}$ & $\begin{array}{l}\text { Unknown fish species, } \\
\text { imported from Albania } \\
\text { to Italy }\end{array}$ & Italy, 1994 & V. cholerae $\mathrm{O} 1$ & Maggi et al., 1997 \\
\hline Eating of dried fish & & $\begin{array}{l}\text { Rural area (Ifakara) in } \\
\text { southern Tanzania, Africa }\end{array}$ & $\begin{array}{l}\text { Vibrio cholerae O1, biotype El } \\
\text { Tor, serotype Ogawa }\end{array}$ & Acosta et al., 2001 \\
\hline $\begin{array}{l}\text { A patient contracted the infection while } \\
\text { handling a fish imported from Nigeria }\end{array}$ & Nigeria & Germany, 2001 & $\begin{array}{l}\text { V. cholerae } 01 \text { serovar Inaba, } \\
\text { biovar El Tor }\end{array}$ & Schürmann et al., 2002 \\
\hline Eating of whitebait imported from Indonesia & Indonesia & Sydney Australia, 2006 & $\begin{array}{l}\text { Vibrio cholerae O1 biotype El } \\
\text { Tor, serotype Ogawa }\end{array}$ & Forssman et al., 2007 \\
\hline
\end{tabular}

Fish may actually benefit from $V$. cholerae that inhabit their intestine. Strains of $V$. cholerae secrete extracellular enzymes such as proteases (Halpern et al., 2003) and chitinases (Pruzzo et al., 2008; Senderovich et al., 2010). These enzymes may have a role in the digestion of macromolecules like proteins and chitin in the fish gut. Chitin, a polymer of $\beta 1,4 \mathrm{~N}$-acetylglucoseamine, is the main component of crustaceans' (copepods) and insects' (chironomids) exoskeletons. This insoluble polymer is a source of carbon and nitrogen (Cohen-Kupiec and Chet, 1998; Laviad et al., 2016). Senderovich et al. (2010) found that all $V$. cholerae strains isolated from 15 different fish species were able to degrade chitin. Thus, it is possible that the fish intestine serves as hosts for $V$. cholerae while the bacteria may play a role in helping the fish digest its chitinous zooplankton prey. As the fish that carry the bacteria swim from one location to another (some fish species move from rivers to lakes or sea and the reverse), they serve as vectors for $V$. cholerae. Nevertheless, fish are consumed by waterfowls, which disseminate the bacteria on a global scale (Halpern et al., 2008; Halpern and Izhaki, 2010).

\section{CONCLUDING REMARKS}

$V$. cholerae non-O1 as well as $\mathrm{O} 1$ and $\mathrm{O} 139$ inhabit highly diverse fish species. In most cases it seems that the bacteria cause the fish no harm; on the contrary, V. cholerae may be a part of the normal flora of at least some of the fish species, like tilapia and carp. Fish might have a mutualistic relationship with $V$. cholerae. The fish provide food and shelter for this bacterium while the bacterium may assist the fish to digest its food (e.g., chitin and protein).
From an epidemiological point of view, the fish carry the cholera bacteria from one place to another. So eventually, if waterbirds feed on the fish, $V$. cholerae may be transferred in some waterbird species' digestive tracts and thus be globally spread.

\section{UNRESOLVED QUESTIONS AND FUTURE RESEARCH}

1. Copepods and chironomids are natural reservoirs of $V$. cholerae. Do fish that feed on these zooplankton species get infected with $V$. cholerae?

2. Is $V$. cholerae transferred vertically or horizontally among fishes? Does an infected female transfer $V$. cholerae to her offspring?

3. Can the bacteria be transferred from one fish species' droppings to another fish species that lives in the same habitat?

4. When the fish intestine becomes infected with $V$. cholerae, does the bacteria become part of its normal microbiota?

5. What are the differences between fish species that carry $V$. cholerae in fresh and marine waters?

6. Does $V$. cholerae prevalence in fish vary by season? Or by different fish age and gender?

7. Can we determine a model fish species that carries $V$. cholerae as against those fish species that do not?

\section{AUTHOR CONTRIBUTIONS}

$\mathrm{MH}$ and II wrote the manuscript and contributed the funding support. 


\section{FUNDING}

This work was supported in part by a grant from the Israel Science Foundation (ISF grant no. 1094/12) and in part by the Binational Science foundation (BSF grant no. 2015103).

\section{REFERENCES}

Acosta, C. J., Galindo, C. M., Kimario, J., Senkoro, K., Urassa, H., Casals, C., et al. (2001). Cholera outbreak in southern Tanzania: risk factors and patterns of transmission. Emerg. Infect. Dis. 7, 583-587. doi: 10.3201/eid0707.017741

Ali, M., Nelson, A. R., Lopez, A. L., and Sack, D. A. (2015). Updated global burden of cholera in endemic countries. PLoS Negl. Trop. Dis. 9:e0003832. doi: 10.1371/journal.pntd.0003832

Booth, L. V., Lang, D. A., and Athersucht, R. (1990). Isolation of Vibrio cholerae non-O1 from a Somerset farm worker and his tropical fish tank. J. Infect. 20, 55-57. doi: 10.1016/S0163-4453(90)92346-M

Broza, M., and Halpern, M. (2001). Chironomids egg masses and Vibrio cholerae. Nature 412:40. doi: 10.1038/35083691

Carvajal, G. H., Sanchez, J., Ayala, M. E., and Hase, A. (1988). Differences among marine and hospital strains of Vibrio cholerae during Peruvian epidemic. J. Gen. Appl. Microbiol. 44, 27-33. doi: 10.2323/jgam.44.27

Chin, C. S., Sorenson, J., Harris, J. B., Robins, W. P., Charles, R. C., Jean-Charles, R. R., et al. (2011). The origin of the Haitian cholera outbreak strain. N. Engl. J. Med. 364, 33-42. doi: 10.1056/NEJMoa1012928

Cohen-Kupiec, R., and Chet, I. (1998). The molecular biology of chitin digestion. Curr. Opin. Biotechnol. 9, 270-277. doi: 10.1016/S0958-1669(98)80058-X

Colwell, R. R., and Huq, A. (2001). Marine ecosystems and cholera. Hydrobiologia 460, 141-145. doi: 10.1023/A:1013111016642

Deshayes, S., Daurel, C., Cattoir, V., Parienti, J. J., Quilici, M. L., and de La Blanchardière, A. (2015). Non-O1, non-O139 Vibrio cholerae bacteraemia: case report and literature review. SpringerPlus 4:575. doi: 10.1186/s40064-015-1346-3

Dong, H. T., Nguyen, V. V., Le, H. D., Sangsuriya, P., Jitrakorn, S., Saksmerprome, V., et al. (2015). Naturally concurrent infections of bacterial and viral pathogens in disease outbreaks in cultured Nile tilapia (Oreochromis niloticus) farms. Aquaculture 448, 427-435. doi: 10.1016/j.aquaculture.2015.06.027

du Preez, M., van der Merwe, M. R., Cumbana, A., and le Roux, W. (2010). A survey of Vibrio cholerae $\mathrm{O} 1$ and $\mathrm{O} 139$ in estuarine waters and sediments of Beira, Mozambique. Wat. SA 36, 615-620. doi: 10.4314/wsa.v36i5.61995

Felsenfeld, O. (1963). Some observations on the cholera (El Tor) epidemic in 1961-62. Bull. Wld. Hlth. Org. 28, 289-296.

Forssman, B., Mannes, T., Musto, J., Gottlieb, T., Robertson, G., Natoli, J. D., et al. (2007). Vibrio cholerae O1 El Tor cluster in Sydney linked to imported whitebait. Med. J. Aust. 187, 345-347. Available online at: https://www.mja. com.au/system/files/issues/187_06_170907/for10584_fm.pdf

Halpern, M., Broza, Y. B., Mittler, S., Arakawa, E., and Broza, M. (2004). Chironomid egg masses as a natural reservoir of Vibrio cholerae nonO1 and non-O139 in freshwater habitats. Microb. Ecol. 47, 341-349. doi: 10.1007/s00248-003-2007-6

Halpern, M., Gancz, H., Broza, M., and Kashi, Y. (2003). Vibrio cholerae Hemagglutinin/Protease Degrades Chironomid Egg Masses. Appl. Environ. Microbiol. 69, 4200-4204. doi: 10.1128/AEM.69.7.4200-4204.2003

Halpern, M., and Izhaki, I. (2010). "The environmental reservoirs and vector of Vibrio cholerae," in Handbook of Disease Outbreaks: Prevention, Detection and Control, eds A. Holmgren and G. Borg (New York, NY: Nova Science Publishers), 309-320.

Halpern, M., Landesberg, O., Raates, D., and Rosenberg, E. (2007). Culturable and VBNC Vibrio cholerae; Interactions with chironomid egg masses and their bacterial population. Microb. Ecol. 53, 285-293. doi: 10.1007/s00248-006-9094-0

Halpern, M., Raats, D., Lavion, R., and Mittler, S. (2006). Dependent population dynamics between chironomids (nonbiting midges) and Vibrio cholerae. FEMS Microbiol. Ecol. 55, 98-104. doi: 10.1111/j.1574-6941.2005.00020.x

\section{SUPPLEMENTARY MATERIAL}

The Supplementary Material for this article can be found online at: http://journal.frontiersin.org/article/10.3389/fmicb. 2017.00282/full\#supplementary-material

Halpern, M., and Senderovich, Y (2015). Chironomid microbiome. Microb. Ecol. 70, 1-8. doi: 10.1007/s00248-014-0536-9

Halpern, M., Senderovich, Y., and Izhaki, I. (2008). Waterfowl — the missing link in epidemic and pandemic cholera dissemination? PLoS Pathog. 4:e1000173. doi: 10.1371/journal.ppat.1000173

Hounmanou, Y. M. G. (2015). Virulence Characteristics and Antibiotic Susceptibility of Vibrio cholerae in Low Quality Water, Fish and Vegetables in Morogoro, Tanzania. A thesis submitted for the degree of Master of Science, Morogoro, Skoine University of Agriculture, 59.

Huq, A., Small, E. B., West, P. A., Huq, M. I., Rahman, R., and Colwell, R. R. (1983). Ecological relationships between Vibrio cholerae and planktonic crustacean copepods. Appl. Environ. Microbiol. 45, 275-283.

Jones, J. L., Benner, R. A. Jr., DePaola, A., and Hara-Kudo, Y. (2013). Vibrio Densities in the intestinal contents of finfish from coastal Alabama. Agric. Food Anal. Bacteriol. 3, 186-194. Available online at: http://aem.asm.org/content/60/ 3/984.long

Kaper, J. B., Morris, J. G. Jr., and Levine, M. M. (1995). Cholera. Clin. Microbiol. Rev. 8, 48-86.

Katz, L. S., Petkau, A., Beaulaurier, J., Tyler, S., Antonova, E. S., Turnsek, M. A., et al. (2013). Evolutionary dynamics of Vibrio cholerae O1 following a single-source introduction to Haiti. MBio 4, e00398-e00313. doi: $10.1128 / \mathrm{mBio} .00398-13$

Kiani, S., Sadat, N., and Nazari, A. (2016). Detection of Vibrio species isolated from ornamental guppy fish in kashan, isfahan, iran fish culturing pounds. Biol. J. Micro 4, 43-48. Available online at: http://bjm.ui.ac.ir/article_19601_ 74b75b7834a23045959d52eb25e8372f.pdf

Kiiyukia, C., Nakajima, A., Nakai, T., Muroga, K., Kawakami, H., and Hashimoto, H. (1992). Vibrio cholerae non-O1 isolated from ayu fish (Plecoglossus altivelis) in Japan. Appl. Environ. Microbiol. 58, 3078-3082.

Killewo, J. Z., Ansi, D. M., and Mhalu, F. S. (1989). An investigation of a cholera epidemic in Butiama village of the Mara Region, Tanzania. J. Diarrhoeal Dis. Res. 7, 13-17.

Kirchberger, P. C., Orata, F. D., Barlow, E. J., Kauffman, K. M., Case, R. J., Polz, M. F., et al. (2016). A small number of phylogenetically distinct clonal complexes dominate a coastal Vibrio cholerae population. Appl. Environ. Microbiol. 82, 5576-5586. doi: 10.1128/AEM.01177-16

Kuberski, T., Flood, T., and Tera, T. (1979). Cholera in the Gilbert Island. I. Epidemiological features. Am. J. Trop. Med. Hyg. 28, 677-684.

Kumar, R., and Lalitha, K. V. (2013). Prevalence and molecular characterization of Vibrio cholerae O1, non-O1 and non-O139 in tropical seafood in Cochin, India. Foodborne Pathog. Dis. 10, 278-283. doi: 10.1089/fpd.2012.1310

Lan, C.-C., and Love, D. R. (2012). Molecular characterisation of bacterial community structure along the intestinal tract of Zebrafish (Danio rerio): a pilot study. ISRN Microbiol. 2012:590385. doi: 10.5402/2012/ 590385

Laviad, S., Golan, A., Shaked, T., Vaizel-Ohayon, D., Halpern, M., and Pick, E. (2016). Aeromonas chitinase degrades chironomid egg masses. Environ. Microbiol. Rep. 8, 30-37. doi: 10.1111/1758-2229.12347

Lewin, S. M. (1996). "Zoological microhabitats of Vibrio cholerae," in Cholera and the Ecology of Vibrio cholerae, eds B. S. Drasar and B. D. Forrest (London: Chapman and Hall), 228-254. doi: 10.1007/978-94-009-1515-2_7

Maggi, P., Carbonara, S., Fico, C., Santantonio, T., Romanelli, C., Sforza, E., et al. (1997). Epidemiological clinical and therapeutic evaluation of the Italian cholera epidemic in 1994. Eur. J. Epidemiol. 3, 95-97. doi: 10.1023/A:1007329700125

McIntyre, R. C., Tira, T., Flood, T., and Blake, P. A. (1979). Modes of transmission of cholera in a newly infected population on an atoll: implications for control measures. Lancet 10, 311-314. doi: 10.1016/S0140-6736(79)90719-0 
Merson, M. H., Martin, W. T., Craig, J. P., Morris, G. K., Blake, P. A., Craun, G. F., et al. (1977). Cholera on Guam, 1974: epidemiologic findings and isolation of non-toxigenic strains. Am. J. Epidemiol. 105, 349-361.

Morgan, M. F., Felsenfeld, O., Rodvatana-Kul, B., Buspavanish, S., Bandhumedha, B., and Chowvanasai, A. (1960). A study pf patients with mild cholera in Bangkok, Thailand sprong 1959. Am. J. Hyc. 72, 250-260.

Pandit, C. G., and Hora, S. L. (1951). The probable role of the hilsa fish, Hilsa ilisa (Ham) in maintaining cholera endemicity in India. Indian J. Med. Sci. 5, 343-356.

Piantieri, G., Pedersoli, G., Cafarelli, A., Bossi, G., and Bignamini, M. L. (1982). Isoation and significance of Vibrio cholerae NAG. [Article in Italian] G. Batteriol. Virol. Immunol. 75, 128-134.

Plesník, V., and Procházková, E. (2006). Vibrio cholerae O1 in a fish aquarium. Epidemiol. Mikrobiol. Imunol. (Article in Czech) 55, 30-31.

Press Release (2003). Food and Environmental Hygiene Department, Vibrio cholerae Found in Supermarket Fish Tank Water. Hong Kong. Available online at: http://www.fehd.gov.hk/news/details/01-09-2003-268.html. (Accessed September 1, 2003).

Pruzzo, C., Vezzulli, L., and Colwell, R. R. (2008). Global impact of Vibrio cholerae interactions with chitin. Environ. Microbiol. 10, 1400-1410. doi: 10.1111/j.1462-2920.2007.01559.x

Reddacliff, G. L., Hornitzky, M., Carson, J., Petersen, R., and Zelski, R. (1993). Mortalities of goldfish, Carassius auratus (L.), associated with Vibrio cholerae (non-O1) infection. J. Fish. Dis. 16, 517-520. doi: 10.1111/j.1365-2761.1993.tb0 0887.x

Rehulka, J., Petras, P., Marejkova, M., and Aldova, E. (2015). Vibrio cholerae nonO1/non-O139 infection in fish in the Czech Republic. Vet. Med. 60, 16-22. doi: 10.17221/7921-VETMED

Rowe, H. M., Withey, J. H., and Neely, M. N. (2014). Zebrafish as a model for zoonotic aquatic pathogens. Dev. Comp. Immunol. 46, 96-107. doi: 10.1016/j.dci.2014.02.014

Runft, D. L., Mitchell, K. C., Abuaita, B. H., Allen, J. P., Bajer, S., Ginsburg, K., et al. (2014). Zebrafish as a natural host model for Vibrio cholerae colonization and transmission. Appl. Environ. Microbiol. 80, 1710-1717. doi: 10.1128/AEM.03580-13

Sack, D. A., Sack, R. B., Nair, G. B., and Siddique, A. K. (2004). Cholera. Lancet 363, 223-232. doi: 10.1016/S0140-6736(03)15328-7

Schürmann, D., Ebert, N., Kampf, D., Baumann, B., Frei, U., and Suttorp, N. (2002). Domestic cholera in Germany associated with fresh fish imported from Nigeria. Eur. J. Clin. Microbiol. Infect. Dis. 21, 827-828. doi: $10.1007 / \mathrm{s} 10096-002-0832-\mathrm{z}$
Senderovich, Y., Gershtein, Y., Halewa, E., and Halpern, M. (2008). Vibrio cholerae and Aeromonas; do they share a mutual host? ISME J. 2, 276-283. doi: 10.1038/ismej.2007.114

Senderovich, Y., Izhaki, I., and Halpern, M. (2010). Fish as reservoirs and vectors of V. cholerae. PLoS ONE 6:e8607. doi: 10.1371/journal.pone.0008607

Smith, K. F., Schmidt, V., Rosen, G. E., and Amaral-Zettler, L. (2012). Microbial diversity and potential pathogens in ornamental fish aquarium water. PLoS ONE 7:e39971. doi: 10.1371/journal.pone.0039971

St. Louis, M. E., Porter, J. D., Helal, A., Drame, K., Hargrett-Bean, N., Wells, J. G., et al. (1990). Epidemic cholera in West Africa: the role of food handling and high-risk foods. Am. J. Epidemiol. 131, 719-728.

Sujatha, K., Senthilkumaar, P., Sangeetha, S., and Gopalakrishnan, M. D. (2011). Isolation of human pathogenic bacteria in two edible fishes, Priacanthus hamrur and Megalaspis cordyla at royapuram waters of Chennai, India. Indian J. Sci. Technol. 4, 539-541. Available online at: http://www.indjst.org/index. $\mathrm{php} /$ indjst/article/view/30057/26011

Thi, A. N. T., Jacxsens, L., Noseda, B., Samapundo, S., Nguyen, B. L., Heyndrickx, M., et al. (2014). Evaluation of the microbiological safety and quality of Vietnamese Pangasius hypophthalmus during processing by a microbial assessment scheme in combination with a self-assessment questionnaire. Fish. Sci. 80, 1117-1128. doi: 10.1007/s12562-014-0786-y

Traoré, O., Martikainen, O., Siitonen, A., Traoré, A. S., Barro, N., and Haukka, K. (2014). Occurrence of Vibrio cholerae in fish and water from a reservoir and a neighboring channel in Ouagadougou, Burkina Faso. J. Infect. Dev. Ctries 8, 1334-1338. doi: 10.3855/jidc.3946

Xing, M., Hou, Z., Yuan, J., Liu, Y., Qu, Y., and Liu, B. (2013). Taxonomic and functional metagenomic profiling of gastrointestinal tract microbiome of the farmed adult turbot (Scophthalmus maximus). FEMS Microbiol. Ecol. 86, 432-443. doi: 10.1111/1574-6941.12174

Yamanoi, H., Muroga, K., and Takagashi, S. (1980). Physyological characteristics and phatogenicity of NAG vibrio isolated from diseased ayu. Fish Pathol. 15, 69-73. doi: $10.3147 /$ jsfp. 15.69

Conflict of Interest Statement: The authors declare that the research was conducted in the absence of any commercial or financial relationships that could be construed as a potential conflict of interest.

Copyright $\odot 2017$ Halpern and Izhaki. This is an open-access article distributed under the terms of the Creative Commons Attribution License (CC BY). The use, distribution or reproduction in other forums is permitted, provided the original author(s) or licensor are credited and that the original publication in this journal is cited, in accordance with accepted academic practice. No use, distribution or reproduction is permitted which does not comply with these terms. 